\title{
Learning to Read and Reading to Learn in English
}

\author{
- Parbati Kumari Pokharel
}

\begin{abstract}
Reading is one of key language skills which enables the readers to learn many things i.e. reading is the gateway of knowledge. Enabling the readers to read in English is one of the major issue in ELT. This article defines reading as the key skill with various reading strategies and comprehension as the goal of reading. It is based on the secondary sources of data basically based on the review of related literature and attempts to review on learning to read and reading to learn in English in particular.
\end{abstract}

Key words: Reading, Comprehension, Learning, Strategies, and Ability

\section{Introduction}

As Anderson (2003, p. 1) claims "reading is an active, fluent process which involves the reader and the reading material in building meaning" and Crystal (2007, p. 209) points out that reading "crucially involves appreciating the sense of what is written: we read for meaning". From the foregoing, one can conclude that, during the reading process, information from visual, semantic, conceptual and linguistic sources combines to make sense of sentence and phrases. Comprehension, which is the essence of reading, is found to be neglected in the teaching learning context of EFL.

Learning to read is not an easy task, even for some children of average intelligence(Westwood, 1997, p. 83). Acquiring literacy becomes more difficult as students grow older; children who do not learn to read in the first few grades are more likely to repeat grades and to eventually drop out of school. The ability to read and comprehend a simple text is one of the most fundamental skills a child can learn. Evidence indicates that learning to read both early and at a sufficient rate (with comprehension) is essential for learning to read well. Children first need to learn to read so that they can read to learn. That is, as children pass through the grade levels, more and more academic content is transmitted to them through text, and their ability to acquire new knowledge and skills depends largely on their ability to read and extract meaning from text. The first and foremost step of education is, no doubt, reading, should be developed from 


\section{Learning to Read and Reading to Learn in English}

the earlier stages of education which is very difficult to develop for the students even in their native language text.

In today' societies, reading is considered as indispensable for a life of high quality (Bahadir 2012, p. 2) as cited in( Akın, Koray, \& Tavukçu, 2015, p. 2445). It is quite important for the individuals' social and academic achievements to gain reading habit after learning how to read and write, and then to begin reading with a critical point of view (Gokturk, 1997). The abilitytoreadandcomprehend text is anecessaryprerequisitefor full participationin modern society. Reading, as a receptive skill, has long been regarded as a prerequisite for foreign language acquisition since it functions as an essential source of input for other skills to develop. Reading also plays a vital role in academic development, particularly when learners have to work over a huge amount of foreign language materials for their own specialist subjects (McDonough and Shaw, 2013). Learning to read is a basic need and right of every young learner throughout the world. McNamara (2007) argues that reading can be challenging, particularly when the material is unfamiliar, technical, or complex. Moreover, for some readers, comprehension is always challenging. They may understand each word separately, but linking them together into meaningful ideas often doesn't happen as it should. These readers can decode the words, but have not developed sufficient skills to comprehend the underlying, deeper meaning of the sentences, the paragraphs, and the entire text (p. xi).

Being a good teacher of reading starts with an understanding of what reading is. What exactly happens between text, brain, and eye when we engage in this delightful, magical practice called reading? Reading is the practice of using text to create meaning. The two key words here are creating and meaning. If there is no meaning being created, there is no reading taking place (Johnson, 2008, p. 4). "It is common place in theories of reading to seek to identify skills which underly or contribute to the reading process"(Alderson, 1990, p. 425). According to Grabe (2009), "reading is a strategic process in that a number of the skills and processes are needed on the part of the reader to anticipate text information, select key information, organize and mentally summarize information, monitor comprehension, repair comprehension breakdowns, and match comprehension output to reader goals" (p. 15). Alderson (2000) points out that "the notion of skills and sub-skills in reading is enormously pervasive and influential, despite the lack of clear empirical justification" (p. 10). Nuttall (1996, pp. 41-78) states that effective reading involves 'word attack' skill; 'sentence attack' skill and 'text attack' skill. To her, reading involves not only looking at sentences and word sand going through them at random but also recognizing and understanding them intellectually. It helps students pick up new words, syntax and style of writing. 


\section{Reading Strategies as the Roadmap for Reading}

Regarding the reading strategies, Garner (1987) says that "reading strategies are an action or a series of actions employed in order to construct meaning." Similarly, Readingstrategies ha vebeendefinedas"thecomprehension processes thatreadersusein ordertomakesenseofwhatthey read"(Brantmeier, 2002, p. 1).The distinction between reading 'skills' and reading 'strategies' are not always clear, and they are sometimes used interchangeably. "It is not always easy to distinguish skills from strategies" (Hudson, 2007, p. 77). According to Rupp, Ferne and Choi (2006), 'skills' are unconscious automatic abilities that facilitate comprehension such as text decoding and the use of background knowledge, while 'strategies' are conscious techniques which are used intentionally for successful reading such as skimming and scanning.

Barnett (1988) defined reading strategies as the mental operations conducted by readers when they purposely read a text for comprehension. According to Paris et al. (1983, p. 293), reading strategies are skills under consideration which closely depend on specific reading contexts as well as readers awareness, control and intention.They range from bottom-up vocabulary strategies, such as looking up an unknown word in the dictionary, to more comprehension actions, such as connecting what is being read to the reader's background knowledge. Block (1986, p. 465) established that reading strategies indicate "how readers conceive a task, what textual cues they attend to, how they make sense of what they read, and what they do when they do not understand". Erler and Finkbeiner (2007) conceptualized comprehension strategies as "intentional actions chosen to facilitate reading at any level of processing" (p. 189).

Block (1986) classified reading strategies as general strategies (comprehension-gathering and comprehension-monitoring) and local strategies (understanding specific language units). Anderson (1991, p. 463) proposed a detailed classification of reading strategies including five major groups: supervising strategies, support strategies, paraphrase strategies, coherence strategies and test-taking strategies. According to Barnett (1988), reading strategies are the comprehension processes which readers use to comprehend what they are reading. These processes may include skimming, scanning, guessing word meanings from context, etc. She argues that using efficient reading strategies will help L2 students to understand more than those who do not. 
Table No. 1: List of Reading Strategies

\begin{tabular}{|c|c|}
\hline Reading Strategies & Description \\
\hline Predicting & $\begin{array}{l}\text { - Helps activate prior knowledge } \\
\text { - Based on clues in text (pictures, subtitles, etc.) }\end{array}$ \\
\hline Connecting & - Connecting prior knowledge to new information \\
\hline Comparing & $\begin{array}{l}\text { - Thinking more specifically about connections they are making, e.g. } \\
\text { How is this different to....? }\end{array}$ \\
\hline Inferring & $\begin{array}{l}\text { - Taking information from a text and creating their own interpretation } \\
\text { beyond the literal level. }\end{array}$ \\
\hline Synthesising & $\begin{array}{l}\text { - Piecing information together as students read a text, to keep track of } \\
\text { what is happening }\end{array}$ \\
\hline Creating Images & - Creating sensory images to assist with overall comprehension of a text \\
\hline Self-questioning & $\begin{array}{l}\text { - Providing a framework for active learning as students engage with the } \\
\text { text to find answers }\end{array}$ \\
\hline Skimming & - Glancing quickly through material to gain an overall view of text \\
\hline Scanning & - Glancing through a text to locate specific details, e.g. names, dates etc. \\
\hline Determining Importance & $\begin{array}{l}\text { - Prioritizing most important information from phrase, sentence, } \\
\text { paragraph, chapter or whole text }\end{array}$ \\
\hline $\begin{array}{l}\text { Summarising and } \\
\text { Paraphrasing }\end{array}$ & $\begin{array}{l}\text { - Reducing larger texts to focus on important elements } \\
\text { - Re-stating/re-writing text in own words using key words to capture } \\
\text { main focus }\end{array}$ \\
\hline Re-Reading & $\begin{array}{l}\text { - Creating opportunities for deeper understanding, word identification } \\
\text { and developing fluency }\end{array}$ \\
\hline Reading On & $\begin{array}{l}\text { - Skipping unfamiliar word(s) and reading on to provide sufficient } \\
\text { context to determine unknown word/phrase }\end{array}$ \\
\hline Adjusting Reading Rate & $\begin{array}{l}\text { - Adjusting rate where appropriate, e.g. slowing down to comprehend } \\
\text { new information, or speeding upto scan for key words }\end{array}$ \\
\hline Sounding Out & - Using knowledge of letter-sound relationship to decode unknown words \\
\hline Chunking & $\begin{array}{l}\text { - Breaking multi-syllabic words into units larger that individual } \\
\text { phonemes }\end{array}$ \\
\hline Using Analogy & $\begin{array}{l}\text { - Transferring what they know about familiar words to help them } \\
\text { identify unfamiliar words }\end{array}$ \\
\hline Consultinga Reference & $\begin{array}{l}\text { - Using a dictionary, thesaurus, reference chart or glossary to help find } \\
\text { word meanings/pronunciations }\end{array}$ \\
\hline
\end{tabular}

\section{Comprehension as the Destination of Reading}

Comprehension is the essence of reading and the active process of constructing meaning from text (Durkin, 1993). Reading comprehension involves the interaction of linguistic processing and conceptual processing and results in the construction of meaning or conceptual representation of a text in the memory. As basic requirements for comprehension, words must be recognized, semantic propositions must be extracted from sentences, and ideas from 
different sentences must be connected to one another (Horiba \& Fukaya, 2015, p. 23). In the words of Davies (1995, p. 185) "reading comprehension is a process of analysis of receiving message from a written text." Reading comprehension is considered to occur at four levels of complexity. These levels are often referred to as literal level, inferential level, critical level and creative level (Smith 1969as cited inWestwood, 2001, p. 21).

Research has shown that general knowledge and familiarity can enhance comprehension of an L2 text (Horiba \& Fukaya, 2015, p. 25). Reading a text requires several cognitive abilities such as memory, problem solving, and making inferences (Nahatame, 2014, p. 54).In "the Comprehension Strategies of Second Language Readers," (Block 1986, pp. 472-473).) categorizes strategies into two levels: general comprehension and local linguistic strategies. The former, general comprehension strategies comprise comprehension gathering and comprehension monitoring strategies, whereas the latter, local linguistic strategies, work on attempts to understand specific linguistic units. Ten kinds of general strategies are:

- Anticipate content: The reader predicts what content will occur in succeeding portions of text.

- Recognize text structure: The reader distinguishes between main points and supporting details or discusses the purpose of information.

- Integrate information: The reader connects new information with previously stated content,

- Question information in the text: The reader questions the significance or veracity of content.

- Interpret the text: The reader makes an inference, draws a conclusion, or forms a hypothesis about the content,

- Use general knowledge and associations: The readers use their knowledge and experience (a) to explain, extend, and clarify content; (b) to evaluate the veracity of content; and (c) to react to content.

- Comment on behavior or process: The reader describes strategy use, indicates awareness of the components of the process, or expresses a sense of accomplishment or frustration.

- Monitor comprehension: The reader assesses his or her degree of understanding of the text.

- Correct behavior: The reader notices that an assumption, interpretation, or paraphrase is incorrect and changes that statement.

- React to the text: The reader reacts emotionally to information in the text.

\section{Below are the Local Strategies:}

- Paraphrase: The reader rephrases content using different words, but with the same sense. 


\section{Learning to Read and Reading to Learn in English}

- Reread: The reader rereads a portion of the text either aloud or silently.

- Question meaning of a clause or sentence: The reader does not understand the meaning of a portion of the text.

- Question meaning of a word: The reader does not understand a particular word.

- Solve vocabulary problem: The reader uses context, a synonym, or some other wordsolving behavior to understand a particular word

Brown (2001), for example, points out that "reading comprehension is a matter of developing appropriate, efficient comprehension strategies" (ibid p. 306). He goes on to enumerate ten such strategies:

- Identify the purpose in reading.

- Use graphemic rules and patterns to aid in bottom-up reading.

- Use different silent reading techniques for relatively rapid reading.

- Skim the text for main ideas.

- Scan the text for specific information.

- Use semantic mapping or clustering.

- Guess when you aren't certain.

- Analyze vocabulary.

- Distinguish between literal and implied meanings.

- Capitalize on discourse markers to process relationships.

\section{Conclusion}

Reading, without question, is a highly complex cognitive process. Learning to read, thus, is the most important educational outcome. Teaching children to read at a young age, therefore, is the cornerstone of improving educational outcomes. Children who do not learn to read in the early grades struggle to develop more advanced skills, which are often absorbed through reading. Unable to understand printed information, follow written instructions and communicate well in writing, these children risk falling further and further behind those who can read effectively in later grades. Children who do not develop the ability to read proficiently in early grades are less likely to complete compulsory education than those who do.

\section{References}

Akın, F. Koray, O. \& Tavukçu,K. (2015). How effective is critical reading in the understanding of scientific texts? Procedia - social and behavioral sciences. Vol. 174, pp.2444- 2451. Alderson, J.C. (2000). Assessing reading. Cambridge: Cambridge University Press.

Anderson, N. J. (1991). Individual differences in strategy use in second language reading and testing. The modern language journal, Vol.75, pp. 460-472. 
Anderson, N. J. (2003). Metacognitive Reading Strategies Increase L2 Performance. The language teacher online. Vol. 27(7): pp.1-3.

Barnett, M. (1988). More than meets the eyes: Foreign language reading. Englewood Cliffs, N. J: Prentice Hall Regents.

Block, E. (1986). The comprehension strategies of second language readers. TESOL Quarterly, Vol. 20 (3), pp.463-494.

Brantmeier, C. (2005). Effects of reader's knowledge, text type, and test type on L1 and L2 reading comprehension. The modern language journal, Vol. 89, pp. 37-53.

Brown, H. D. (2001). Teaching by principles: An interactive approach to language pedagogy. Englewood Cliffs, New Jersey: Prentice Hall Regents

Crystal, D. (2007). How language works: how babies babble, words change meaning, and languages live or die, USA: Avery Pub Group

Davies, F. (1995).Introducing reading. London: Penguin.

Durkin, D. (1993). Teaching them to read (6 ${ }^{\text {th }}$ Ed.). Boston: Allyn \& Bacon.

Grabe, W. (2009). Reading in a second language: Moving from theory to practice. New York, NY: Cambridge University Press.

Erler, L., \& Finkbeiner, C. (2007). A review of reading strategies: Focus on the impact of first language. In A. D. Cohen \& E. Macaro (Eds.), Language learner strategies (pp.187206). Oxford, UK: Oxford University Press.

Horiba, Y., \& Fukaya, K. (2015). Reading and learning from L2 text: Effects of reading goal, topic familiarity, and language proficiency. In Reading in a Foreign Language: Vol. 27(1), pp. 22-46.

Hudson, T. (2007). Teaching second language reading. Oxford: Oxford University Press

Johnson, P. (2008). Effects on reading comprehension of language complexity and cultural background of a text. TESOL Quarterly, Vol. 15(2), pp. 169-81.

McDonough, J. \& Shaw, C. (2013) Materials and Methods in ELT: A Teacher's Guide. (3 ${ }^{\text {rd }}$ ed). Oxford: Blackwell.

Nahatame, S. (2014). Strategic processing and predictive inference generation in L2 reading . In Reading in a Foreign Language: Vol. 26( 2), pp. 54-77.

Nuttall, C. (1996). Teaching reading skills in a foreign language. Heinemann.

Paris, S., Lipson, M. \& Wixson, K. (1983).Becoming a Strategic Reader. Contemporary Educational Psychology, Vol. 8, pp. 293-316.

Rupp, A., Ferne, T., \& Choi, H. (2006). How assessing reading comprehension with multiplechoice questions shapes the construct: A cognitive processing perspective. Language testing, Vol. 23 (4), pp. 441-74.

Westwood, P. (1997). Common sense methods for children with special education needs. ( $3^{\text {rd }}$ ed.). Routledge Falmer: New York.

Westwood, P. (2001). Reading and learning difficulties: approaches to teaching and assessment. The Australian Council for Educational Research Ltd : Camberwell, Victoria. 